pp. $365-376$

\title{
The Role of Authenticity and Satisfaction on Tourists' Revisit Intention at Air Soda Destination
}

Submitted 15/07/20, $1^{\text {st }}$ revision 19/08/20, $2^{\text {nd }}$ revision $11 / 09 / 20$, accepted $30 / 09 / 20$

\author{
Pantas H. Silaban ${ }^{1}$, Andri D.K. Silalahi ${ }^{2}$, Edgar Octoyuda ${ }^{3}$, \\ Donita Panjaitan 4
}

\begin{abstract}
:
Purpose: This research was conducted to empirically analyzed the influence of authenticity on revisit intention mediated by the tourists' satisfaction at Air Soda destination, Indonesia.

Design/Methodology/Approach: The research uses 160 respondents taken randomly in the destination. Using the purposive random sampling and some criteria for respondents the sample consists of (1) visiting the destination at least two times, (2) the respondent is at least 20 years old. The research used Structural Equation Modelling (SEM) to analyze the data and to test the model.

Findings: Authenticity significantly influenced tourists' satisfaction but insignificantly influenced revisit intention. Tourists' satisfaction significantly influenced revisit intention. Authenticity mediated by tourists' satisfaction significantly influenced revisit intention.

Practical Implications: The results of this research show the constructed authenticity as the most influential in tourists' revisit intention. Tourism stakeholders should focus their attention on the development of constructed authenticity. Integrating local wisdom and culture into the tourists' experience enhancing the development of constructed authenticity and will contribute to the sustainability of the destination visited by tourists.

Originality/Value: The model shows that authenticity mediated by the tourists' satisfaction influences revisit intention in the destination. Constructed authenticity of the destination plays an important role in increasing the number of tourists visiting the destination.
\end{abstract}

Keywords: Authenticity, tourists' satisfaction, revisit intention.

Paper type: Research article.

JEL codes: $M 21$.

Paper Type: Research Article.

ISSN: 2241-4754, H index 10, Q3.

${ }^{1}$ Postgraduate School, University of HKBP Nommensen Medan, Indonesia,

e-mail: pantas.silaban@uhn.ac.id;

${ }^{2}$ Same as in 1, e-mail: andri.silalahi@student.uhn.ac.id;

${ }^{3}$ Same as in 1, e-mail: edgar.tampubolon@ student.uhn.ac.id;

${ }^{4}$ Faculty of Economy, University of HKBP Nommensen Medan, Indonesia,

e-mail: donitapanjaitan@gmail.com; 


\section{Introduction}

Tourism is one of Indonesia's economic sectors that is continuously developed in each region of the country. Contribution of tourism to the country's foreign exchange reaches $12 \%$ of the total 12 commodities that are the source of foreign exchange (Indonesia Ministry of Tourism, 2015). Tourism increasingly developed in line with social, cultural, economic, technological, and political changes. One of the most important elements in developing the tourism sector is increasing the number of visits. This will, in the term, create economic exchanges at the destination.

Tourist destinations have authenticity or special characteristics to attract tourists. The research about authenticity nowadays is increasing. Many perspectives of authenticity appeared scientifically by research. Zhang et al. (2018) research the authenticity, cross-culture awareness, and acculturation on tourist satisfaction. The research explains the high interest of tourists to visit the authenticity of destinations such as historical, cultural, local sites, architecture, traditional houses, and cultural and historical sites. One of the determining factors for tourist satisfaction is the authenticity of the destinations that are preserved by the tour managers. Further, tourists' satisfaction positively impacts the tourists' revisit intention (Aswati and Sudarso, 2019). Air Soda tourism destination is rare. North Tapanuli has Air Soda tourism destination located in Parbubu village. North Tapanuli is a part of the North Sumatera province in Indonesia. There are two Air Soda tourism destinations globally, one of them is in Venezuela, and another is in North Tapanuli, Indonesia. This rare tourism resource is valuable to improve the number of tourists' visits when it is managed-well.

Statistically, yearly visitors' data from 2014 until 2018 have shown significantly increased each year (Central Bureau Statistic North Tapanuli Regency, 2019). This should make North Tapanuli feel proud of its potential and make it a featured destination in the area. For this reason, it is necessary to have the roles of both parties of government and tour managers in the development of tourism destinations. Knowing the attributes of tourism and improving its quality by empowering the local culture and creating Air Soda to be a cultural destination. That will make Air Soda destination more attractive and competitive. The increasing number of tourists visiting in the area will be reviewed to revisit intention, tourist satisfaction, and authenticity of a destination. Improving the quality of tourism by utilizing authenticity becomes a good strategy for a featured destination in the area of attractiveness and competitiveness to develop destination sustainability.

\section{Literature Review and Hypotheses}

\subsection{Authenticity on Tourists' Satisfaction and Revisit Intention}

Authenticity is defined as a concept regarding originality about objective, constructed, and existential authenticity (Zhang et al., 2018). Camus (2010) 
responds to authenticity theory, which refers to authenticity, purity, and lies outside the commercial scope that focuses on food products: origin, uniqueness, tourist projection site, donor-free and non-profit. Furthermore, the basic concept of authenticity focuses on the authenticity (originality) of a particular tourist attraction.

Authenticity is a concept regarding a certain tourist destination's originality, which involves three types or classifications consisting of objective authenticity, constructed authenticity, and existential authenticity. Zhang et al. (2018) prove that authenticity influenced the tourists' satisfaction. In his research, objective authenticity is a major factor in creating tourists visiting destinations listed as historical site destinations. This research uses the concept of authenticity to measure the level of tourist satisfaction also revisit intention. Several authors investigate the concept of authenticity following the classifications above (MacCannell, 2002; Wang, 1999; Zhang et al., 2018). Ramkissoon and Uysal (2010) also found that authenticity influence revisits behavior from the tourist. The authenticity is a featured aspect for increasing behavioral intentions to a destination, including the satisfaction and revisited tourists' intentions on a destination (Park et al., 2018). Revisit intention can be described as a feeling of revisiting a tourist destination in the future and recommending destinations to others (Aswati and Sudarso, 2019). According to Pakirti et al., (2017), tourists' revisit intention is positive behavior after purchasing services. Thus, the concept of revisit intention equated with the interest of returning to visit. Two research hypotheses stated as:

$H_{1}$ : Authenticity positively and significantly influences revisit intention.

\section{$\mathrm{H}_{2}$ : Authenticity positively and significantly influences tourists' satisfaction.}

\subsection{Tourists' Satisfaction and Revisit Intention}

Tourist satisfaction is the main goal of the tourism industry (Sadeh et al., 2018). In this case, satisfaction refers to the experience of a visit made to a certain tourist destination. The definition of tourist satisfaction is the level of affirmative emotion and awareness formed after the individual participates in the intended recreational activity (Beard and Ragheb, 1980). Currently, tourist satisfaction has been linked to the cultural elements of a particular tourist destination. Several studies have linked tourist satisfaction with cultural elements (Zhang et al., 2018; Truong et al., 2017; Wang, 2009). Tourists' satisfaction is an overall measure of tourist experience on each destination's quality (Prayag, 2008; Coban, 2012). Tourist satisfaction is the result of interactions between tourists' experiences and expectations before and after a product or service (Purwaningsih, 2013). Kotler and Keller (2009) suggest that satisfaction is the feeling of being happy or disappointed by someone that arises from comparing the product's perceived performance (or results) against their expectations. According to Um et al. (2006), revisit intention becomes a positive impact on satisfaction. This means revisit intention is the impact of satisfaction behavior from the tourist on a destination. The tourist satisfaction factor determines 
the sustainability of the tourism industry. The following research states that the importance of tourist satisfaction in supporting the sustainability of the tourism industry (Del Bosque and San Martín, 2008; Hasegawa, 2010; Sukiman et al., 2013; Yürük et al., 2017; Chen et al., 2018; Silaban et al., 2019). The research hypothesis is stated as:

\section{$H_{3}$ : Tourists' satisfaction positively and significantly influences revisit intention.}

\subsection{Mediating Role of Tourists' Satisfaction}

Many research topics about authenticity, tourists' satisfaction, and revisit intention have not discussed the mediating role of tourists' satisfaction between authenticity and revisit intention. This research was conducted to analyze tourists' mediating role in relationships of authenticity to revisit intention. According to Yen (2020), authenticity becomes a moderating variable in analyzing satisfaction and revisit intention. However, tourists' satisfaction and revisit intention are variables that cannot be separated. These can be used to analyze the effect of tourism variables (Chou, 2013). This research can be used as an original theory that finds relationships between authenticity to revisit intention.

$H_{4}$ : Tourists' satisfaction positively and significantly influences the authenticity on revisit intention.

\section{Research Methodology}

This research used explanatory research design to explain, describe, and provide empirical evidence or provide a clear description of a phenomenon and solve it theoretically by analyzing the primary data. Primary data used in this research and collected by distributing questionnaires to respondents using a random sampling technique. The number of samples used in this research was 160 respondents using the formula $\mathrm{n}=10 \mathrm{x}$ (number of latent variables + number of indicators) (Hair et al., 2010). The sampling technique used is purposive random sampling using the following criteria: (1) tourists who have visited Air Soda tourism destination at least 2 times; (2) tourists who have visited the destination in the past year; (3) tourists who are at least 20 years old.

The data instrument with a questionnaire using a Likert scale consisting of strongly agree $=5$, agree $=4$, disagree $=3$, disagree $=2$ and strongly disagree $=1$. In this research, validity and reliability testing used confirmatory factor analysis (CFA) and average variance extracted (AVE). Furthermore, the suitability of the model using the goodness of fit (GOF) criteria as follows: Chi-square $=$ nearer to zero, CMIN/DF $\leq 2,00 ;$ RMSEA $\leq 0,08 ;$ GFI $\geq 0,90 ;$ CFI $\geq 0,90 ;$ NFI $\geq 0,90 ;$ TLI $\geq 0,90 ;$ AGFI $\geq$ 0,90 and probability/p-value $\geq 0,05$. A thought is proposed and uses a Structural Equation Modeling (SEM) approaches to analyze the relationship between the 
constructs in the research. SEM is globally acceptable in both academic and social science studies (Hair et al., 2010; Jackson, 2003).

\section{Results and Discussion}

\subsection{Results}

This research was conducted at the Air Soda destination in North Tapanuli Regency. The Air Soda is one of the bathing attractions located in the foothills of the Tarutung area, in Parbubu I Village, North Tapanuli Regency. The number of questionnaires distributed in this study was 220, but only 160 were returned and fill out by the respondents correctly. The characteristics of respondents are shown in Table 1:

Table 1. Research Respondents

\begin{tabular}{|l|l|l|}
\hline Gender & Frequencies & Percentage (\%) \\
\hline Male & 79 & 49,4 \\
\hline Female & 81 & 50,6 \\
\hline Total & 160 & 100 \\
\hline Age & 87 & 60,6 \\
\hline $20-30$ & 52 & 32,5 \\
\hline $31-45$ & 11 & 6,9 \\
\hline$>45$ & 160 & 100 \\
\hline Total & \multicolumn{2}{|l|}{} \\
\hline Occupations & 47 & 29,4 \\
\hline Student & 24 & 15,0 \\
\hline Government Employee & 55 & 34,4 \\
\hline Entrepeneur & 34 & 21,3 \\
\hline Others & 160 & 100 \\
\hline Total & 66 & 41,3 \\
\hline Visits frequencies & 58 & 36,3 \\
\hline $2-3$ & 22 & 13,8 \\
\hline $4-5$ & 14 & 8,8 \\
\hline $6-7$ & 160 & 100 \\
\hline$>7$ & \multicolumn{2}{|l}{} \\
\hline Total &
\end{tabular}

Source: Primary Research Data, 2020

Testing the validity and reliability of the data in this research used Confirmatory Factor Analysis (CFA) and Average Variance Extracted (AVE) instruments. If the CFA value $>0.60$ and the AVE value $>0.05$, the variable's construct is valid and reliable to use for the next testing date (Table 2 ). The validity and reliability of the constructs above indicate that entire constructs meet the criteria' validity and reliability assumptions. Therefore, the data is valid and reliable if used in further data testing. Furthermore, testing for structural research model that will be used as a tool to test the hypothesis. The data for the final structural model of the research are shown in Figure 1. 
Table 2. Validity and Reliability Test

\begin{tabular}{|c|c|c|c|c|}
\hline Research Variable & Indicators & $\begin{array}{l}\text { Standard } \\
\text { Loadings }\end{array}$ & AVE & Conclusion \\
\hline \multirow[t]{6}{*}{ Revisit Intention (Y) } & Future Visit & 0,93 & \multirow[t]{6}{*}{0,168} & \multirow[t]{6}{*}{ Supported } \\
\hline & Tourist Priority & 1,40 & & \\
\hline & Frequent Visit & 1,09 & & \\
\hline & Revisit Willingness & 1,06 & & \\
\hline & Revisit Plan & 0,74 & & \\
\hline & Attempt to Revisit & 1,00 & & \\
\hline \multirow{10}{*}{$\begin{array}{l}\text { Tourists' Satifaction } \\
\text { (Z) }\end{array}$} & Feel happy & 1,00 & \multirow[t]{10}{*}{0,120} & \multirow[t]{10}{*}{ Supported } \\
\hline & $\begin{array}{l}\text { Value and useful for the } \\
\text { journey }\end{array}$ & 0,80 & & \\
\hline & Attraction sites & 2,80 & & \\
\hline & Transportation & 2,18 & & \\
\hline & Price & 1,16 & & \\
\hline & Local hospitality & 1,01 & & \\
\hline & View & 1,30 & & \\
\hline & Access & 2,47 & & \\
\hline & Available Facility & 1,40 & & \\
\hline & Road Infrastructure & 1,00 & & \\
\hline \multirow[t]{3}{*}{ Authenticity } & Objective authenticity & 0,81 & \multirow[t]{3}{*}{0,103} & \multirow[t]{3}{*}{ Supported } \\
\hline & Constructed authenticity & 1,22 & & \\
\hline & Existential authenticity & 1,00 & & \\
\hline
\end{tabular}

Source: Data Analytical Result, 2020

Figure 1. Final Structural Model

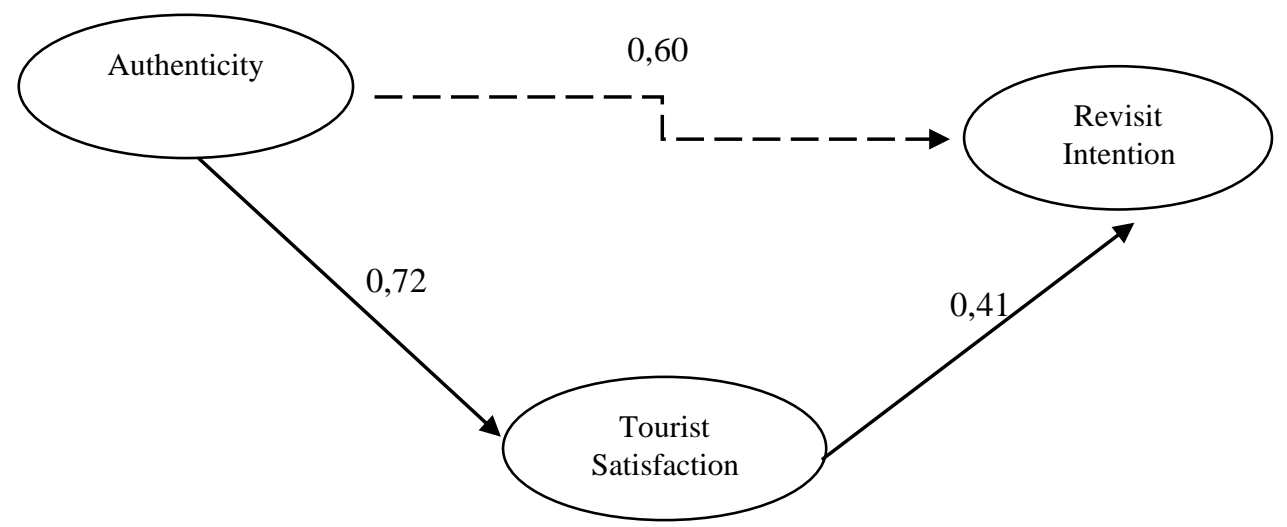

Source: Result of Research Data Analysis, 2020

Explanation:

$$
\begin{array}{ll} 
& =\text { Significant } \\
----- & =\text { Not Significant }
\end{array}
$$


Based on the results obtained, the relationship with the dotted line's impact explains an insignificant relationship, while the straight line indicates a significant relationship. The results of this research's structural model have been obtained through several tests using the modified index on the output of Amos version 22.

The results in Figure 1 can be further explained through the goodness of fit criteria set out above. The following are the results of the final structural model goodness of fit criteria in this research (Table 3):

Table 3. Final Evaluation of Fit Overall Model

\begin{tabular}{|l|l|l|l|l|}
\hline No & Testing Criteria & $\begin{array}{l}\text { Cut Off Value } \\
\text { (Standard Statistic) }\end{array}$ & $\begin{array}{l}\text { Cut off Value } \\
\text { Results }\end{array}$ & Conclusion \\
\hline 1 & Chi Square & nearer to 0 & 142.309 & Supported \\
\hline 2 & CMIN/DF & $<2,00$ & 1.129 & Supported \\
\hline 3 & RMSEA & $<0,08$ & 0,029 & Supported \\
\hline 4 & GFI & $\geq 0,90$ & 0,922 & Supported \\
\hline 5 & CFI & $\geq 0,90$ & 0,963 & Supported \\
\hline 6 & NFI & $\geq 0,90$ & 0,769 & Marginal \\
\hline 7 & TLI & $\geq 0,90$ & 0,950 & Supported \\
\hline 8 & Probability & $\geq 0,05$ (Marginal) & 0,152 & Marginal \\
\hline 9 & AGFI & $\geq 0,90$ & 0,883 & Marginal \\
\hline
\end{tabular}

Source: Result of Data Analysis, 2020.

Based on the criteria, the final evaluation for the structural model can be seen several criteria has not met the assumptions, but the mandatory values such as RMSEA = 0.029 , GFI $=0.922$, and CFI $=0.963$ have met, this means the critical value for fulfilling the model assumptions has been achieved. Therefore, the results of the research structural model can be used in testing the research hypothesis.

The hypothesis test in this research was conducted in two ways, direct and indirect impact. Hypothesis testing in this study was conducted using critical ratio criteria $\mathrm{CR}>1.96$ and the $\mathrm{p}$-value $<0.05$. It can be concluded that the hypothesis $(\mathrm{Ha})$ is supported if the CR $>1.96$ and the p-value $<0,05$ or instead. The following are a summary of hypothesis testing in this research, as shown in Table 4:

Table 4. Summary of Hypothesis Testing Result

\begin{tabular}{|c|c|c|c|c|c|}
\hline Hyphotesis & $\begin{array}{l}\text { Critical } \\
\text { Ratio } \\
(1,96)\end{array}$ & $\begin{array}{l}p- \\
\text { value } \\
(0,05)\end{array}$ & $\begin{array}{l}\text { Critical } \\
\text { Ratio } \\
\text { Results }\end{array}$ & $\begin{array}{l}p \text {-value } \\
\text { Results }\end{array}$ & Conclusion \\
\hline Direct Hypothesis & \multirow{4}{*}{1,96} & \multirow{4}{*}{0,05} & & & \\
\hline $\begin{array}{l}\text { Authenticity } \rightarrow \quad \text { Revisit } \\
\text { Intention }\end{array}$ & & & 1,837 & 0,066 & Unsupported \\
\hline $\begin{array}{l}\text { Authenticity } \\
\text { Satisfaction }\end{array}$ & & & 2,277 & 0,023 & Supported \\
\hline $\begin{array}{ll}\text { Tourists' Satisfaction } & \rightarrow \\
\text { Revisit Intention } & \\
\end{array}$ & & & 1,977 & 0,048 & Supported \\
\hline
\end{tabular}




\begin{tabular}{|c|c|c|c|}
\hline Indirect Hypothesis & & & \\
\hline $\begin{array}{lrr}\text { Authenticity } \rightarrow & \text { Revisit } \\
\text { Intention through } & \text { Tourists' } \\
\text { Satisfaction } & \end{array}$ & 3,452 & 0,001 & Supported \\
\hline
\end{tabular}

Source: Result of Data Analysis, 2020.

The results of the hypothesis testing above indicate that:

1. Authenticity has a positive and insignificant impact the revisit intention;

2. Authenticity has a positive and significant impact on the tourists' satisfaction;

3. Tourist satisfaction has a positive and significant impact on the revisit intention; and

4. The tourist satisfaction positively and significantly mediates the authenticity towards revisiting intention.

Furthermore, the result of the coefficient of determination in this research shows that there are three constructs, both endogenous and exogenous constructs. For exogenous constructs, authenticity consists of three manifest variables. The most influential manifest variable of authenticity is constructed authenticity, with a $31.3 \%$ effect on the Air Soda destination's authenticity. This means that constructed authenticity is the most influential factor for tourists to visit Air Soda Destination. Secondly, revisit intention, which consists of six manifest variables with the strongest influence on intention to revisit, is a future visit with the magnitude of the influence of $31.1 \%$. Furthermore, the construct of tourists' satisfaction consisting of ten manifests with the most influencing manifest is transportation with $26.3 \%$.

\subsection{Discussion}

\subsubsection{Authenticity on Revisit Intention}

Authenticity in a research perspective focuses on the side of a tourist destination sighted from the first objective authenticity, which an objective side is in the form of historical relics, historic places, and other forms of heritage that are still preserved until this day. Second, constructed authenticity focuses on historical heritage in any form modified and still maintained or preserved until now, which is packaged by the tourism manager into a tourism product. The third is existential authenticity, the value of historical heritage, including cultural values that are still embraced by the local community, which is used to serve the needs of tourists.

This research's object is a historical site that contains an element of authenticity name to be Air Soda bath. Air Soda bath's location is in the North Tapanuli Regency, where most of the population is the indigenous Batak Toba people. The results of this research show that the construct of authenticity is the most affecting construct. These findings open a new perspective of introducing constructed authenticity to a variety of historical sites and authentic sides combined with 
constructed authenticity. In constructing the constructed authenticity, Air Soda destination can improve the quality and variability by combining new constructs and stringing up local culture into the destination. Potential aspects of culture such as local culinary, local arts and music, local custom. The famous traditional food of Batak people such as naniura, tombur, and tuak. Providing such specific local culinary will improve the attractiveness and quality of experience visiting the destination. This shows the importance of providing services based on local wisdom in the element of authenticity. When delivering tourist services to the tourist-packed in the form of local, it will increase the value, increasing the intention of a revisit. Authenticity is a concept that summarizes the genuineness and the originality. Tourists who visit tourist destinations are divided into authenticity characteristics, which share interest indicators for intention to revisit. This analytical relationship is also supported by previous research which analyzed authenticity on the revisit intention (Casteran and Roederer, 2013) which stated that there was no relationship between authenticity on revisit intention.

\subsubsection{Authenticity on the Tourist's Satisfaction}

Tourist satisfaction is the most important element in forming a sustainable tourist destination. Sustainable tourist destinations can certainly be applied when there is a synergy among the tourist destination managers with other stakeholders around the tourist destination, including the government. From the authenticity point of view of the Air Soda destination, after analyzing the data it is proved that the authenticity was able to give a significant influence on the tourist's satisfaction. This means that the better the package of the concept of local wisdom or authenticity of a tourist destination combined with local culture will increase the satisfaction of tourists as well. Authenticity is a concept of genuineness, originality of a particular tourist destination to analyze motivation, authenticity and the connection with tourist satisfaction. Several other studies have analyzed that there is a positive relationship between tourist satisfaction (Purwanigsih, 2013) which states that authenticity affects tourist satisfaction. Therefore, it is important to increase tourist satisfaction by utilizing local culture / local wisdom that can be seen from the authenticity of the tourist destination itself. This study found that constructed authenticity is the most dominant variable affecting tourist satisfaction (Zhang et al., 2018). Therefore, in increasing tourist satisfaction on the object of this research, tourism stakeholders need to study various alternatives in generating constructed authenticity. Constructed authenticity is determined from the diversification of Air Soda services that can answer the needs of visiting tourists by utilizing local community services.

\subsubsection{Tourist Satisfaction on the Revisit Intention}

The research of the tourist satisfaction on the revisit intention is expected to give contributions and thoughts about sustainable tourism. The concept of revisit analyzed based on tourist satisfaction is an initial strategy to establish a sustainable tourism concept. In this research, the concept of tourist satisfaction is examined more complex by adding accessibility elements, service quality, and individual sense of tourists on their visit to a destination called an Air Soda bath. A simple concept of 
satisfaction is that satisfaction will occur when customer expectations are fulfilled or exceeded by visiting the tourist's preferred destination. Analyzing motivation and tourist satisfaction and its relations between revisit intention significantly affect the revisit intention. The result of this research conducted by Sangkaeng et al. (2015) stated a relation between tourist satisfaction on the revisit intention.

\subsubsection{Authenticity on the Revisit Intention Mediation Variables of Tourist Satisfaction}

The result of this research, the variable of tourist satisfaction mediates relations between authenticity variables and tourist revisit intention to an Air Soda destination located in North Tapanuli Regency. In this research, it is important to clarify that authenticity cannot significantly influence the revisit intention but must be mediated by tourist satisfaction. This means that in addition to visiting a destination with high authenticity, tourists also attach importance to other supporting elements while attending in destination such as transportation, after visiting feelings, accessibility, or affordability, and so on. Obviously, this is very influential in forming the intention of a revisit. The relations among each variable depend on tourist perception on their visit. To explain the differences in the relations between authenticity on the revisit intention is in the intervening variable. The result of the direct and indirect impact in this research determines the sustainability of tourist destination as seen from increasing the desire of tourist to revisit.

\section{Conclusions and Recommendations}

The conclusions obtained from the result of this research are as follows:

1. Authenticity insignificantly impact on revisit intention;

2. Authenticity significantly impact on tourists' satisfaction;

3. Tourist satisfaction significantly impact on revisit intention;

4. Tourist satisfaction significantly mediates the authenticity of revisit intention.

Based on this research, constructive authenticity is the most influencing on tourists' satisfaction. In terms, the tourists' satisfaction increases the revisit intention of a destination. Revisit intention can be impacted by destination sustainability. Based on the research, it is recommended that:

1. The tour manager should increase the services to attract the tourist by providing tourists needs based on local culture;

2. Integrate the local culture to the services culture such as local culinary, local arts and music, local custom;

3. Services classification need to be provided to meet the differential characteristics of the tourist's needs;

4. The tour manager and other stakeholders should collaborate to increase the quality of services and sustainability of a destination. 


\section{References:}

Aswati, L., Sudarso, E. 2019. The Influence of Brand Image, Service Quality and Accessibility on Revisit Intention at Hongkong Inn Sang Kawang Hotel. Jurnal Pendidikan Ekonomi, 4(1).

Beard, J.G., Ragheb, M.G. 1980. Measuring Leisure Satisfaction. Journal of Leisure Research, 12(1), 20-33.

Camus, S. 2010. L'authenticite d'un site touristique, ses antecedents et ses influences surle touriste. Gestion, 27(1), 101-117.

Castéran, H, Roederer, C. 2013. Does authenticity really affect behavior? The case of the Strasbourg Christmas Market. Tourism Management. Elsevier, 36(C), 153-163.

Chen, C.C., Huang, W.J., Gao, J., Petrick, J.F. 2018. Antecedents and Consequences of Work-Related Smartphone Use on Vacation: An Exploratory Study of Taiwanese Tourists. Journal of Travel Research, 57(6), 743-756.

Chou, H.J. 2013. The Effect of the Visitor's Consumption Experience and Tourism Image on Tourist Satisfaction and Revisit Intention of Taiwan's Night Markets. GSTF Journal on Business Review, (GBR), 3(1).

Coban, S. 2012. The Effects of the Image of Destination on Tourist Satisfaction and Loyalty: The Case of Cappadocia. European journal of Social Sciences, 29(2), 222-232.

Del Bosque, I.R., San Martín, H. 2008. Tourist satisfaction a cognitive-affective model. Annals of Tourism Research, 35(2), 551-573.

Hair, J.F., Ringle, C.M., Sarstedt, M. 2011. PLS-SEM: Indeed, a silver bullet. Journal of Marketing Theory and Practice, 19(2), 139-151.

Hasegawa, H. 2010. Analyzing tourists' satisfaction: A multivariate ordered Probit approach. Tourism Management, 31(1), 86-97.

Jackson, D.L. 2003. Adding Missing-Data-Relevant Variables to FIML-Based Structural Equation Models, Structural Equation Modeling, 37-41.

Kotler, P., Keller, K. 2009. Marketing Management. Prentice Hall, $13^{\text {th }}$ Edition. New Jersey.

MacCannell, D. 2002. Staged Authenticity: Arrangements of Social Space in Tourist Settings. American Journal of Sociology, 79(3), 589-603.

Pakirti, S., Kusumawati, A., Mawardi. 2017. The Influence of City Branding and Tourism Event on Visit Decision and its Impact on Tourists' Revisit Intention to Banyuwangi Regency. Jurnal Administrasi Bisnis (JAB), 47(1).

Park, S., Hwang, D., Lee, W.S., Heo, J. 2018. Influence of nostalgia on authenticity, satisfaction, and revisit intention: The case of Jidong mural alley in Korea. International Journal of Hospitality \& Tourism Administration, 1-17.

Prayag, G. 2008. Image, Satisfaction and Loyalty - The Case of Cape Town, Anatolia: An International Journal of Tourism and Hospitality Research, 19(2), 205-224.

Purwaningsih, R. 2013. The Influence of Service Quality of Tour guide on Tourists' Satisfaction in Prambanan Temple. Jurnal Nasional Parawisata, 5(3), 146-153.

Ramkissoon, H., Uysal, M.S. 2011. The effects of perceived authenticity, information search behaviour, motivation and destination imagery on cultural behavioural intentions of tourists. Current Issues in Tourism, 14(6), 537-562.

Sadeh, E., Asgari, F., Mousavi, L., Sadeh, S. 2012. Factors Affecting Tourist Satisfaction and Its Concequances. Journal of Basic and Applied Scientific Research, 2(2), 11571560.

Sangkaeng, S., Mananeke, L., Oroh, S.G. 2015. The Influence of Image, Promotion and Service Quality of a Destination on Tourists Satisfaction in Taman Laut Tourism Destination North Sulawesi. Jurnal Manajemen, Bisnis dan Akuntansi, 3(3). 
Silaban, P.H., Pasaribu, A., Silalahi, A. 2019. The influence of human aspect of accommodation and destination on tourist satisfaction. International Journal of Innovative Technology and Exploring Engineering, 8(7C2), 140-143.

Sukiman, M.F., Omar, S.I., Muhibudin, M., Yussof, I., Mohamed, B. 2013. Tourist Satisfaction as the Key to Destination Survival in Pahan. Procedia-Social and Behavioral Sciences, 91, 78-87.

Truong, T.L.H., Lenglet, F., Mothe, C. 2018. Destination distinctiveness: Concept, measurement, and impact on tourist satisfaction. Journal of Destination Marketing \& Management, 8, 214-231.

Um, S., Chon, K., Ro, Y. 2006. Antecedents of revisit intention. Annals of Tourism Research, 33(4), 1141-1158.

Wang, N. 1999. Rethinking authenticity in tourism experience. Annals of Tourism Research, 26(2), 349-370

Yen, T.F. 2020. The Determinates of Revisit Intentions in Wine Cultural Event: The Moderating Role of Experience Authenticity. Asian Journal of Education and Social Studies, 6(4), 27-40.

Yürük, P., Akyol, A., Şimşek, G.G. 2017. Analyzing the effects of social impacts of events on satisfaction and loyalty. Tourism Management, 367-378.

Zhang, H., Cho, T., Wang, H., Ge, Q. 2018. The Influence of Cross-Cultural Awareness and Tourist Experience on Authenticity, Tourist Satisfaction and Acculturation in World Cultural Heritage Sites of Korea. Sustainability, 10(4), 927, MDPI AG. Retrieved from http://dx.doi.org/10.3390/su10040927. 